Int. J. Dev. Biol. 55: 353-363

doi: $10.1387 / \mathrm{ijdb} .103213 \mathrm{sp}$

\title{
Signal transduction in vasculogenesis and developmental angiogenesis
}

\author{
SUNITA PATEL-HETT and PATRICIA A. D'AMORE* \\ Schepens Eye Research Institute and Departments of Ophthalmology and Pathology, \\ Harvard Medical School, Boston, MA, USA
}

\begin{abstract}
The vasculature is a highly specialized organ that functions in a number of key physiological tasks including the transport of oxygen and nutrients to tissues. Formation of the vascular system is an essential and rate-limiting step in development and occurs primarily through two main mechanisms, vasculogenesis and angiogenesis. Both vasculogenesis, the de novo formation of vessels, and angiogenesis, the growth of new vessels from pre-existing vessels by sprouting, are complex processes that are mediated by the precise coordination of multiple cell types to form and remodel the vascular system. A host of signaling molecules and their interaction with specific receptors are central to activating and modulating vessel formation. This review article summarizes the current state of research involving signaling molecules that have been demonstrated to function in the regulation of vasculogenesis and angiogenesis, as well as molecules known to play a role in vessel maturation, hypoxia-driven angiogenesis and arterial-venous specification.
\end{abstract}

KEYWORDS: blood vessel formation, vascular development, endothelium, vascular endothelial growth factor

\section{Introduction}

The importance of the circulatory system is evidenced by its emergence early in development. In vertebrates, the circulatory system is the first functional organ system to arise and is critical in providing adequate oxygen and nutrient delivery to rapidly developing tissues, above what can be provided by diffusion alone. The vasculature is formed through three main cellular processes: vasculogenesis, angiogenesis and arteriogenesis. Vasculogenesis, the de novo formation of blood vessels, gives rise to the first blood vessels, establishing a primary vascular plexus. Angiogenesis, the growth of blood vessels from pre-existing blood vessels, allows for dramatic expansion of the vascular plexus, while arteriogenesis involves an increase in arterial vessel diameter in response to increased blood flow or shear stress. Through these three mechanisms a circulatory system is formed and remodeled into a complex vessel system that mediates a wide range of vital physiological processes including tissue oxygenation, nutrient delivery and waste removal, immune response, temperature regulation, and the maintenance of blood pressure.

Precise coordination of cellular events allows for the formation and modification of the vascular system, and molecular signaling by numerous molecules is known to play a pivotal role in activating and modulating these events. In this review we will summarize the current state of research involving signaling molecules known to function in the regulation of vasculogenesis and angiogenesis.

\section{Vasculogenesis}

Development of the circulatory system begins soon after gastrulation concomitant with somite formation. The process of vessel formation at this early stage of development is vasculogenesis, a term coined by Risau and colleagues in 1988 (Risau and Lemmon, 1988; Risau et al., 1988) and described as the de novo formation of blood vessels from the differentiation and association of endothelial progenitor cells.

Previous studies examining vasculogenesis concluded that blood vessel formation occurs both intra- and extra-embryonically (Reagan, 1915; Sabin, 1920). The embryonic mesoderm, as well as the extra-embryonic yolk sac, allantois and placenta have been identified as sources of vascular endothelial and hematopoietic progenitor cells and are sites of vasculogenesis (Caprioli et al., 2001). In the murine yolk sac, the precursor cells migrate, differentiate and associate into clusters called blood islands at embryonic day (E) 6.5-7 (Fig. 1). Within the blood islands, a subset of peripherally located blood island cells, called angioblasts, undergo further dif-

\footnotetext{
Abbreviations used in this paper: E, embryonic day; VEGF, vascular endothelial growth factor
}

\footnotetext{
*Address correspondence to: Patricia A. D'Amore. Schepens Eye Research Institute and Departments of Ophthalmology and Pathology, Harvard Medical School, 20 Staniford Street, Boston, MA 02114, USA. Fax: +1-617-912-0128. E-mail: pattidamore@gmail.com
} 
ferentiation into endothelial cells at E8.5, while internally situated cells become hematopoietic precursors that will give rise to blood cells (Fig. 1). The term hemangioblast was given to the common blood island precursor cell that eventually gives rise to both endothelial and hematopoietic cells (His, 1900). The endoderm has also been shown to be critical to angioblast differentiation.

Angioblasts, highly motile cells, are first seen in extra-embryonic tissues and then within the embryo itself in close apposition to the endoderm. Extra-embryonic angioblasts develop alongside hematopoietic progenitor cells, while embryonic angioblasts develop unaccompanied (Pardanaud and Dieterlen-Lievre, 1993). Angioblasts proliferate, migrate and associate to form primitive, tube-like vessels. Vessel formation occurs through either the coalescence of angioblasts, as occurs in construction of the dorsal aorta, or migration of angioblasts from distant sites, as seen in the formation of the ventral aorta and cardinal veins.

Vessel development proceeds as angioblasts differentiate into endothelial cells, form a vascular lumen and deposit a basal lamina (Fig. 1). In the yolk sac, vasculogenesis results in the formation of a primitive vascular plexus. Within the embryo, vasculogenesis contributes to the formation of capillaries in the head mesenchyme and endocardium. By the 2 somite stage, intra-and extra-embryonic vasculature has anastomosed while the embryo is still capable of retrieving oxygen through diffusion (Risau and Flamme, 1995). The plexus then connects to the developing heart tube prior to the initiation of a heartbeat. In addition to establishing the primary vascular plexus, vasculogenesis mediates vascularization in a number of organs including the liver, spleen, and lung (Pardanaud and Dieterlen-Lievre, 1993; Ribatti et al., 2009). Furthermore, roles for vasculogenesis have also been described in adults such as capillary formation following ischemic injury (Asahara et al., 1997; Tongers et al., 2010).

\section{Signaling in vasculogenesis}

Compared to angiogenesis, considerably less is understood about the molecular signals regulating vasculogenesis. Investigations of vasculogenesis in an array of in vivo models have demonstrated a significant role for a number of growth factors, which we describe in this section.

\section{Fibroblast growth factors}

Fibroblast growth factors (FGFs) have been implicated in early vascular development. In mammals, the FGF family consists of 18 paracrine or endocrine peptide factors, which possess a homologous core domain and differentially activate several FGF tyrosine kinase receptors (Beenken and Mohammadi, 2009). In particular, FGF-2 has been implicated in mesodermal induction and the induction of angioblasts from the mesoderm (Cox and Poole, 2000).

\section{The hedgehog family}

The hedgehog family of morphogens including, sonic hedgehog (Shh), Indian hedgehog (Ihh) and desert hedgehog (Dhh), have been shown to have important roles in the formation of the vasculature at various stages of development. Binding of Hedgehog ligands to their transmembrane receptor, Patched, induces a conformational change that relieves repression of the transmembrane smoothened protein. Activation of smoothened expression allows GLI transcriptional activators (GLI-A) to accumulate and activate
A

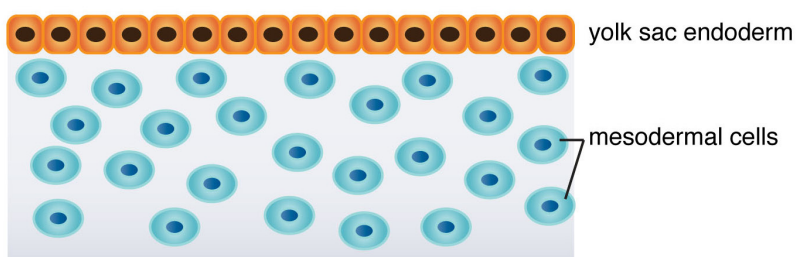

B

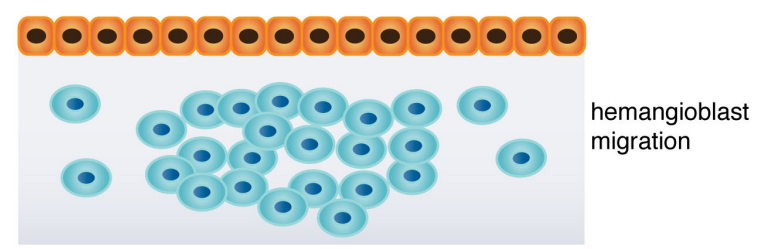

C

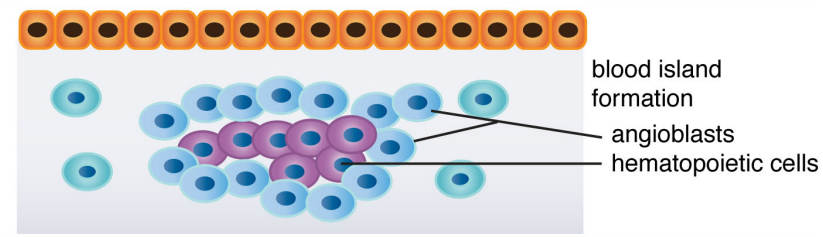

D

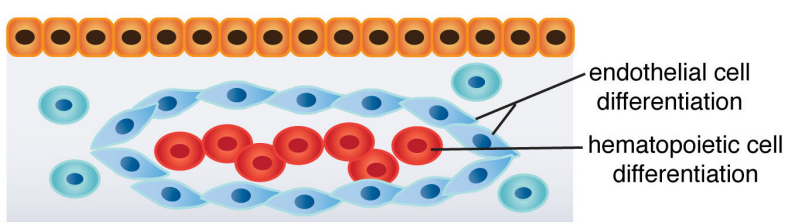

$\mathbf{E}$

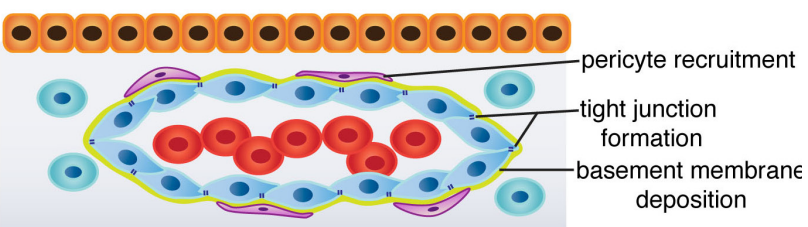

Fig. 1. Schematic of extra-embryonic vasculogenesis. (A) Endodermal cells (orange) induce mesodermal cells (aqua), initiating vasculogenesis. (B) Hemangioblasts migrate and associate. (C) Blood islands containing centrally located hematopoietic precursor cells (purple) and peripherally localized angioblasts (blue) are formed. (D) Angioblasts differentiate to endothelial cells (blue) and hematopoietic cells (red) further differentiate. (E) Lumenization occurs, tight junctions (dark blue dashes) form between endothelial cells and a basement membrane (green) is deposited along the basolateral endothelial cell surface. The association of pericytes (magenta) is correlated with the deposition of the basement membrane and marks vessel maturation.

hedgehog target genes (Jenkins, 2009; Riobo et al., 2006). Of the three hedgehog molecules, Ihh has been implicated as a requirement for appropriate blood island formation in yolk sac vessel development (Dyer et al., 2001) and endothelial tube formation in the murine embryo (Vokes et al., 2004). Ihh-deficient mice display defective yolk sac angiogenesis (Byrd et al., 2002), a finding that was recently confirmed by pharmacological inhibition of hedgehog signaling (Nagase et al., 2006).

\section{The VEGFs and VEGF receptors}

It has been well established that vascular endothelial growth factor (VEGF) signaling has essential roles in vasculogenesis and angiogenesis. The VEGF protein family consists of a number of 
secreted glycoproteins: VEGF-A, VEGF-B, VEGF-C, VEGF-D, endocrine gland VEGF (EG-VEGF), VEGF-E, VEGF-F, VEGF-b and placental growth factor (PIGF). Of these, VEGF-A, originally identified as vascular permeability factor (Senger et al., 1990) has been the most widely studied VEGF family member and has been implicated in both vasculogenesis and angiogenesis. VEGF-B has been shown to play a central role in cardiac development (Aase et al., 2001; Bellomo et al., 2000). VEGF-C and VEGF-D promote lymphatic vessel development (Karkkainen et al., 2003; Tammela and Alitalo, 2010; Tammela et al., 2005) and may also contribute to angiogenesis (Cao et al., 1998). EG-VEGF appears to be a highly specific isoform that acts only on the endocrine gland endothelial cells (LeCouter et al., 2001). VEGF-b, a splice variant of the VEGF-A gene, has been shown to possess anti-angiogenic activity (Bates et al., 2002; Woolard et al., 2004). PIGF, originally identified in the placenta (Maglione et al., 1991), occurs at low levels in the embryo and adult and has been primarily studied in pathological conditions where it is thought to stimulate angiogenesis in coordination with VEGF-A (Carmeliet et al., 2001).

Four main isoforms of VEGF-A occur through differential splicing of the human Vegf gene. The isoforms of 121, 165, 189 and 206 amino acids differ in their ability to bind heparan sulfate proteoglycans and neuropilin. The largest isoforms (VEGF 206 and VEGF 188) bind heparan sulfate with high affinity and associate with the extracellular matrix, while the smallest isoform (VEGF 121) has low heparan sulfate affinity, is freely diffusible and thus forms a gradient away from its source of secretion. VEGF 165, which displays intermediate binding affinity, has been shown to exhibit the strongest mitogenic response (Keyt et al., 1996).

VEGF family members interact with three main receptors, VEGFR-1 (FIt-1), VEGFR-2 (KDR in humans and Flk-1 in mouse) and VEGFR-3 (Flt-4), all tyrosine kinase receptors and members of the PDGF receptor family. VEGF receptors possess an extracellular domain consisting of immunoglobulin repeats responsible for VEGF binding and intracellular tyrosine kinase domains (Fig. 2). VEGF-A, VEGF-B and PIGF bind to VEGFR-1. VEGF-A, cleaved forms of VEGF-C and VEGF-D, VEGF-E, and VEGF-F and VEGF-b bind VEGFR-2, whereas the unprocessed forms of VEGF-C and VEGF-D bind to VEGFR-3 (Fig. 2). VEGF-A and its receptors VEGFR-1 and VEGFR-2 are expressed early in embryonic development. VEGF$A$ is expressed in the extra-embryonic endoderm and mesoderm as blood islands are assembled and within the intra-embryonic endoderm at E8.5 (Patan, 2000). VEGFR-2 is an early marker of endothelial and hematopoietic precursor cells in blood islands (Choi et al., 1998; Yamaguchi et al., 1993).

Genetic studies demonstrate the requirement for VEGF and VEGF receptors in vasculogenesis. Embryos lacking VEGFR-2 die early in development at approximately E9 due to a failure to initiate vasculogenesis and hematopoiesis (Shalaby et al., 1995). The lack of vessel and blood cell formation was deemed to be the result of defective blood island formation due to impaired cell migration (Shalaby et al., 1997). Embryos lacking VEGF are similarly embryonic lethal due to severe vascular defects. Deletion of even a single VEGF allele results in embryonic lethality at E11 with defects in formation of the dorsal aorta and development of blood cells (Carmeliet et al., 1996; Ferrara et al., 1996). Embryos lacking VEGFR-1 are also embryonic lethal and exhibit vascular defects. In this case, the angioblasts associated with blood islands localize inappropriately to the central regions of blood islands instead of the periphery (Fong et al., 1995), indicative of endothelial cell overgrowth rather than inhibition. This has led to the suggestion that VEGFR-1 may inhibit VEGF signaling by sequestering it. Deficiency of VEGFR-3, which is expressed on blood vessels early in development, but later becomes restricted to lymphatic vessels, also impacts blood vessel development, although its major role is in lymphatic vessel development. Embryos lacking VEGFR-3 initiate vasculogenesis and angiogenesis, but major cardiovascular defects result in death at E9.5, well before the onset of lymphatic vessel formation. The precise role of VEGFR-3 in blood vessel formation is unclear.

Binding of VEGF ligands to their respective receptors induces receptor homodimerization or heterodimerization, which activates receptor kinase activity, receptor autophosphorylation and downstream signaling. Activation of VEGFR-2 leads to strong autophosphorylation, whereas activation of VEGF-1 results in weak autophosphorylation and signaling. The interaction of VEGFs with VEGFR-2 has been widely studied and appears to play a central role in stimulating endothelial cell migration, differentiation, proliferation and survival.

The VEGF receptors possess multiple tyrosine residues that have been identified as autophosphorylation sites, with some residues regulating intrinsic kinase activity (Eichmann et al., 1997) and other residues functioning as docking sites for signaling molecules (Fig. 3). Phosphorylation at Tyr1054 and Tyr1059 are required for maximal VEGFR-2 activation (Kendall et al., 1999). Tyr1175 of VEGFR-2 acts as a docking site for phospholipase Cgamma (PLC- $\gamma$ ), which activates mitogen-activated protein kinase (MAPK) to promote endothelial cell proliferation (Lyttle et al., 1994; Takahashi et al., 2001). PLC- $\gamma$ in turn leads to calcium release and activation of protein kinase $C$ (PKC) pathways. These pathways induce the transcription factors NFAT and EGR-1, respectively, to

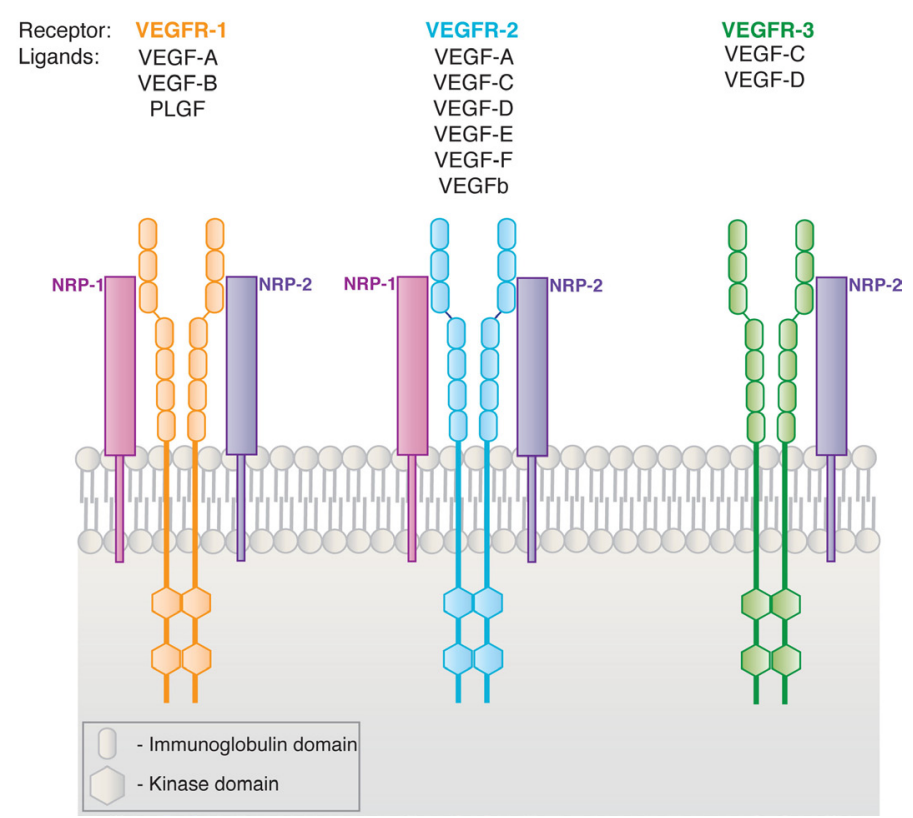

Fig. 2. Vascular endothelial growth factor (VEGF) receptors and their ligands. VEGFR-1 (orange), VEGFR-2 (blue) and VEGFR-3 (green) are depicted. Ligands known to activate the receptors are displayed above each receptor. Neuropilins-1 (red) and-2 (purple), co-receptors forVEGFreceptors, are also shown adjacent to the receptors with which they associate. 
trigger the angiogenic response (Hofer and Schweighofer, 2007; Mechtcheriakova et al., 1999; Mechtcheriakova et al., 2001). PLC- $\gamma /$ PKC also activate protein kinase D (PKD) phosphorylation of histone deacetylase 7 (HDAC7) resulting in endothelial cell proliferation and migration (Wang et al., 2008). Src homology 2 and $\beta$ cell (Shb), a phosphatidylinositol 3 kinase (PI3K) adaptor molecule, also binds to the phosphorylated Tyr1175 residue of VEGFR-2 (Holmqvist et al., 2004) and promotes endothelial cell migration. PI3K activates the Akt/PKB pathway, which mediates endothelial cell survival (Dayanir et al., 2001; Fujio and Walsh, 1999; Olsson et al., 2006)

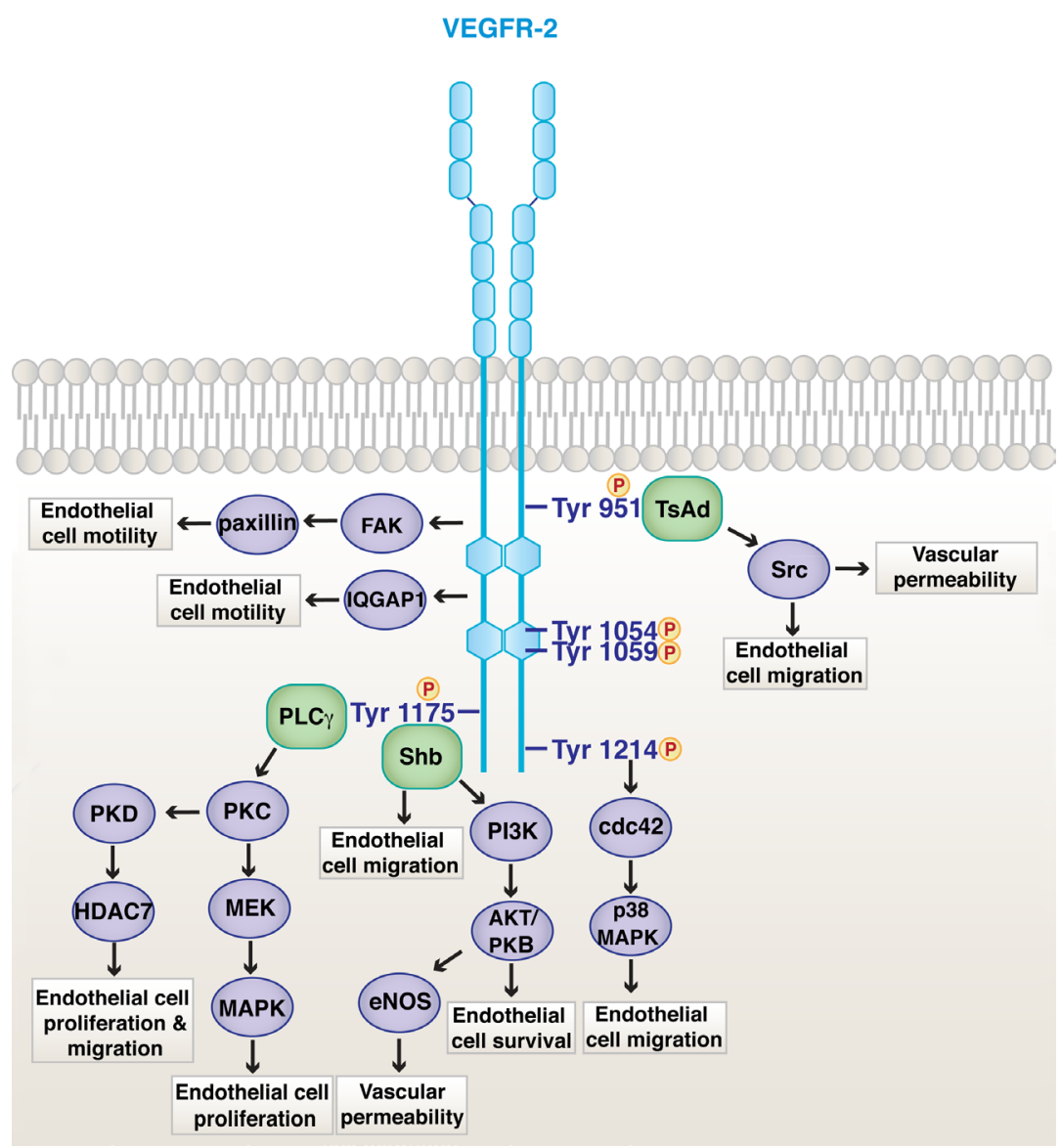

Fig. 3.The vascular endothelial growth factor receptor 2 (VEGFR-2) signaling cascade and effects. The VEGFR-2 homodimer (blue) and its phosphorylated residues known to facilitate signaling are shown. Proteins that bind to VEGFR-2 are depicted (green) along with their downstream targets (purple). Phosphorylation of VEGFR-2 Tyr1054 and Tyr1059 residues are required for maximal receptor activation. Binding of TSAd to phosphorylated residue Tyr951 enhances endothelial cell migration and vascular permeability through Sro activation. Phosphorylation of residueTyr 1175 recruits $P L C \gamma$, which activates $P K C$ to activate endothelial cell proliferation and migration through PKD or the MAPK pathways. Tyr1175 is also a docking site for Shb, which activates endothelial cell migration or endothelial cell survival through the PI3K and AKT/PKB pathway. Phosphorylation of Tyr1214 subsequently activates cdc42 and p38MAPK to induce endothelial cell migration. Finally, phosphorylation of VEGFR-2 also activates FAK and paxillin and IQGAP to stimulate endothelial cell motility. Abbreviations:VEGFR-2 (vascular endothelial growth factor receptor-2); TsAd (T-cell specific adaptor); Tyr (tyrosine); FAK (focal adhesion kinase), IQGAP1 (IQ motif containing GTPase activating protein 1); PLC $($ (phospholipase C gamma); Shb (Src homology 2 and $\beta$ cells); PKC (protein kinase C); MEK (mitogen-activated protein kinase/extracellular signal-regulated kinase kinase); MAPK (mitogen-activated protein kinase); PKD (protein kinase D); HDAC7 (histone deacetylase 7); PI3K (phophatidylinositol3'-kinase); PKB (protein kinase B); eNOS (endothelial nitric oxide synthase). and vascular permeability through its activation of endothelial nitric xide synthase (eNOS) (Fukumura et al., 2001). Phosphorylation VEG-2 at Tyr1214 promotes endothelial cell migration by p38 MAPK (Lamalice et al, 2004). VEGFR-2 Tyr951 represents a docking site for T-cell specific adaptor (TsAd) which associates meability (Matsumoto et al., 2005). Through activation of Rac, Src also induces vascular permeability (Gavard and Gutkind, 2006). cules involved in the regulation of endothelial motility following VEGFR-2 activation include focal adhesion kinase (FAK) and paxillin, and IQ containing GTPase activating protein (IQGAP) (Suchting et al., 2007; Taylor et al., 2002) (Fig. 3). VEGFR-1 is proposed to interact with a number of signaling molecules, including phospholipase $\mathrm{C}-\gamma$, growth factor receptor bound protein 2 (Grb2) and Nck (Kowanetz and Ferrara, 2006; Olsson et al., 2006).

\section{Neuropilins}

VEGFs also signal through neuropilins which function as co-receptors for the VEGF receptors. The neuropilins are transmembrane glycoproteins with short cytoplasmic domains; it remains unclear whether neuropilins are capable of independent signaling (Gaur et al., 2009). Neuropilin signaling occurs through association with plexins or VEGF receptors. Plexins are a family of nine large transmembrane proteins that signal upon semaphorin binding to neuropilins. Endothelial cells differentially express neuropilins; neuropilin-1 is found on arterial endothelium, whereas neuropilin-2 is restricted to venous and lymphatic endothelium. VEGF-A, VEGF-B, VEGF-E and PIGF bind to neuropilin-1, which then associates with either VEGFR-1 or VEGFR-2. Neuropilin-2 binds VEGF-A, VEGF-C, VEGF-D and PIGF, then complexes with VEGFR-1, VEGFR-2 or VEGFR-3. Mutational studies have implicated neuropilins in vasculogenesis. Neuropilin-1 mutants display vascular defects (Kawasaki etal., 1999) whereas, neuropilin-2 mutants show no blood vascular abnormalities, but display defective lymphangiogenesis (Chen etal., 2000; Giger etal., 2000). However, together the neuropilins have been deemed to play roles in vasculogenesis, since mice lacking both neuropilins fail to undergo yolk sac vasculogenesis and lack a primary vascular plexus (Takashima et al., 2002).

\section{TGF- $\beta$ and TGF- $\beta$ receptors}

Transforming growth factor- $\beta$ (TGF $\beta$ ) is a cytokine known to function during vasculogenesis. The TGF $\beta$ family encompasses an array of members including the TGF $\beta$ s (TGF $\beta 1$, TGF $\beta 2$, TGF $\beta 3$ ), bone morphogenetic proteins, activins and inhibins (Rossant and Howard, 2002). TGF $\beta$ family members bind to two types of receptors, type I and type II. Upon activation of the Type 1 family of receptors, which include seven members, smads are phosphorylated, then translocate to the nucleus to activate transcription of target genes (Chen et al., 1998; Hoodless and Wrana, 1998). The five Type 
II receptors, including TGF $\beta R$ RI, undergo conformational changes upon ligand binding and activate type I receptors. Endothelial cells express TGF $\beta$ RII, a serine threonine kinase receptor, and the type I receptors Alk1 and Alk5. Alk1 phosphorylation activates smad1, smad5 and smad8 whereas Alk5 activates smad2 and smad3, which then complex with smad4 to activate transcription in the nucleus. Endothelial cells also express endoglin, a co-receptor that can alter TGF $\beta$ signaling response (Barbara et al., 1999; Letamendia et al., 1998).

Studies examining the effects of TGF $\beta$ on endothelial cells have produced conflicting data, underscoring the complexity of TGF $\beta$ signaling. In vitro studies initially indicated that TGF $\beta$ inhibited endothelial proliferation and migration (Baird and Durkin, 1986; Frater-Schroder et al., 1986). However, other studies suggested a mitogenic role for TGF $\beta$ on endothelial cells (Iruela-Arispe and Sage, 1993, RayChaudhury and D'Amore, 1991; Sutton et al., 1991). These differences in TGF $\beta$ action could be due to differences in dose since low doses of TGF $\beta$ upregulate angiogenic factors, whereas high doses appear to inhibit endothelial cell growth (Hofer and Schweighofer, 2007). Contradictory results were also observed in vivo with studies showing both pro-angiogenic and anti-angiogenic roles for TGF $\beta$ (Li et al., 2001; Roberts et al., 1986). TGF $\beta$ treatment of endothelial cells induces a number of genes associated with the extracellular matrix, including fibronectin and collagens I, IV and V (Rossant and Howard, 2002).

With targeted deletion of TGF $\beta 1$, half of the mutant embryos die at E9.5-E10.5 due to defective yolk sac vasculogenesis while half survive several weeks before succumbing to inflammation (Dickson et al., 1995; Goumans and Mummery, 2000; Letterio et al., 1994). Ablation of TGF $\beta$ RII also results in embryonic lethality at E10.5 due to defective vasculogenesis in the yolk sac and embryo (Larsson et al., 2001; Oshima et al., 1996). Finally, deletion of endoglin results in lethality at E11.5 with major vascular and angiogenic defects as well as growth retardation and abnormal cardiac development (Li et al., 1999). Deletion of Alk1 or Alk5 similarly causes lethality in embryos due to vascular defects, suggesting that these TGF $\beta$ signaling pathways are not redundant. In humans, mutations in endoglin and Alk1 result in hereditary hemorrhagic telangiectasia (HHT), a vascular disorder characterized by arterio-venous malformations, external bleeding and telangiectases (Azuma, 2000).

\section{Angiogenesis}

Angiogenesis is defined as the formation of new vessels by the sprouting of endothelial cells of pre-existing vessels or intussusceptive angiogenesis (IA), the translumenal insertion of tissue pillars within existing capillaries to form new vessels. Angiogenesis commences in the embryo by E9.5 and mediates the formation of the majority of embryonic blood vessels. Angiogenesis is also responsible for the vascularization of organs derived from the ectoderm-mesoderm, including the brain and kidney.

Much research into the mechanisms of angiogenesis followed after Judah Folkman proposed the inhibition of angiogenesis as a means of tumor treatment (Folkman, 1971). Based on an array of studies, we now understand that sprouting angiogenesis is a coordinated series of events centered on endothelial cells (Karamysheva, 2008; Patan, 2000). Vascular sprouts are led by specialized endothelial "tip cells" that are responsive to angiogenic stimuli (Gerhardt et al., 2003) and connected to endothelial stalk cells that function in tube formation. The progression of angiogenesis is initiated by local destruction of the basement membrane of a vessel and the dissociation of pericytes from the capillary, followed by migration of tip cells toward an angiogenic stimulus. Proliferation and alignment of endothelial cells follows as an endothelial cell tube forms, establishing a lumen. Pericyte and/or smooth muscle cell association and basement membrane deposition mediate vessel stabilization.

IA, another mechanism of angiogenesis, is the expansion of the capillary network through a complex re-modeling process that involves insertion of tissue columns within existing vessels (Makanya et al., 2009; Patan, 2000). IA consists of three distinct processes including intussusceptive microvascular growth (IMG), intussusceptive arborization (IAR) and intussusceptive branch remodeling (IBR). IMG is initiated by contact between endothelial cells on opposing capillary walls, which organize into structural elements called the pillar core within the vessel. Peri-endothelial cells, including pericytes and myofibroblasts, invade the pillar core upon which collagen fibrils that stabilize the pillar core are synthesized. Formation of a basement membrane completes the process (Patan, 2000). IAR contributes to expansion of the vascular tree through formation of smaller vessels (Djonov et al., 2000). Finally, IBR allows for modulation of vessel structure and number in response to local blood supply demands (Djonov et al., 2002).

\section{Regulation of angiogenesis}

The goal of limiting blood vessel growth in tumors has led to much investigation of angiogenesis and its regulation in health and disease, which has provided a broad understanding of how angiogenesis is controlled on a cellular and molecular level. As part of this work, a number of proteins that modulate angiogenesis have been identified and their mechanisms of action have been elucidated. The VEGF family of proteins and their receptors play critical roles in stimulating angiogenesis, as previously described for vasculogenesis. In addition to the VEGFs, a number of additional factors important for proper regulation of angiogenesis are described below.

\section{Notch signaling}

Notch signaling is involved in determining the fate of multiple cell types. The Notch family of receptors and their ligands also control endothelial cell sprouting during embryonic vascular development. Four Notch receptors (Notch 1, 2, 3 and 4) are expressed in mammals. Five Notch ligands have been identified, including Jagged1, Jagged2, Delta like ligand (DII) 1, DII3 and DII4. In the vasculature, Notch 1 and 4 are expressed by the endothelium, whereas Notch 3 functions in smooth muscle cells. Activation of Notch receptors results in proteolytic cleavage of the receptor at two distinct sites. A disintegrin and metalloproteinase (ADAM) initially cleaves the receptor within its extracellular domain, resulting in release of the extracellular domain with its bound ligand (Jakobsson etal., 2009). This complex is able to be trans-endocytosed by neighboring cells where it can influence signaling. Cleavage by ADAM is thought to induce a conformational change in the receptor allowing gamma secretase to mediate a second cleavage within the membrane, resulting in the release of the Notch intracellular domain (NICD). NICD then traffics to the nucleus where it interacts with the transcription factor $\mathrm{C}$ promoter binding factor $1(\mathrm{CBP})$ to activate transcription 
of downstream targets, including the Hes and Hey helix-loop-helix genes (Shawber et al., 2003).

Genetic studies have implicated the Notch signaling pathway in the regulation of angiogenesis. Notch 1 null mice die at E11 and although they possess a normal primary vascular plexus, they eventually display vessel degeneration and abnormal vessel remodeling (Krebs, 2000). Notch 1 and 4 double homozygous mutants show increased vascular disruption compared to Notch 1 null homozygotes, including defects in large vessel formation, indicative of a role for both Notch 1 and Notch 4 in vessel development (Krebs, 2000). Constitutively active Notch signaling in endothelial cells similarly leads to impaired vessel formation resulting in embryonic death at E10 (Uyttendaele et al., 2001). Deletion of Jagged1 results in death at E10 due to defective somite formation, lack of vitelline vessels and vascular hemorrhage (Hrabe de Angelis et al., 1997; Xue et al., 1999). Dll4, which binds to both Notch 1 and Notch 4, both expressed by endothelial cells, appears to play a critical role in angiogenesis. Deletion of a single copy of DII4 results in embryonic death (Krebs et al., 2004).

Notch and VEGF signaling appear to be intimately associated in angiogenesis. VEGF has been demonstrated to induce the expression of DII4 and Notch signaling (Liu et al., 2003). Elevated DII4 and VEGFR-2 expression was detected in tip cells compared to neighboring stalk cells (Benedito et al., 2009). In animal models, blockade of VEGF caused a decrease of DIl4 in vessels and inhibited sprouting (Suchting et al., 2007) whereas administration of VEGF induced Dll4 expression (Lobov et al., 2007). Notch signaling also influences VEGF receptors expression, leading to the downregulation of VEGFR-2, as evidenced by decreased VEGFR-2 levels after Notch activation in endothelial cells and in DIl4-deficient mice (Suchting et al., 2007; Taylor et al., 2002). Thus, Notch appears to act as a negative feedback mechanism to regulate VEGF signaling. This regulation may explain the observation that decreased VEGFR-2 allows for local differentiation of endothelial tip cells prior to sprout initiation with VEGF action on tip cells leading to increased DIl4 expression and activation of Notch signaling, which in turn downregulates VEGFR-2 in neighboring stalk cells. Tip cells with higher VEGFR-2 expression will, therefore, readily respond to VEGF while stalk cells with fewer receptors will be less responsive. Interestingly, tip cells do not proliferate in response to VEGF, but rather form filopodia and migrate in the direction of the VEGF gradient; instead it is the stalk endothelial cells of the growing capillary branch that proliferate (Gerhardt et al., 2003).

\section{Semaphorins}

Semaphorins are a family of secreted or membrane-bound glycoproteins that were originally identified as mediators of axonal guidance during neural development. Four classes of vertebrate semaphorins, classes 3-7, have been identified and letters designate individual members of these classes. All semaphorins possess a highly conserved $\mathrm{N}$-terminal sema domain that is required for their function (Capparuccia and Tamagnone, 2009).

Class 3 semaphorins, which bind to neuropilins, have been shown to function as inhibitors of angiogenesis. The class 3 semaphorins comprise seven soluble, secreted glycoproteins designated A-G. Upon semaphorin binding, neuropilins complex with plexins that initiate intracellular signaling. Class 3 semaphorins exhibit differential binding to the neuropilins; Sema3A preferentially binds neuropilin-1, Sema3F and Sema3G bind to neuropilin-2 and Sema3B,
Sema3C and Sema3D bind to both neuropilin-1 and 2. Sema3E appears to bypass interaction with either neuropilin and instead binds directly to plexin D1, triggering signaling (Gu et al., 2005). Sema3A and Sema3F display anti-angiogenic effects, including inhibition of endothelial cell proliferation, migration and survival (Bielenberg et al., 2004; Guttmann-Raviv N, 2007; Kessler et al., 2004; Miao et al., 1999) as well as inhibition of tumor growth and tumor angiogenesis (Bielenberg et al., 2004; Kessler et al., 2004; Kigel et al., 2008). Sema3B and Sema3F have been proposed to function as tumor suppressors due to their downregulation in human cancers (Brambilla et al., 2000; Roche et al., 1996; Tse et al., 2002; Xiang et al., 2002). Interestingly, Sema3C has been shown to elicit a pro-angiogenic response, upregulating integrin activity in endothelial cells (Banu et al., 2006).

\section{Netrins}

Netrins, similar to semaphorins, function in the regulation of both axonal guidance and angiogenesis. A family of secreted proteins, netrins bind to either the deleted in colorectal cancer (DCC) or uncoordinated-5 (UNC5) receptors. The UNC5 receptor has been identified in arterial endothelium and endothelial tip cells. Mice lacking functional UNC5 die at E12.5 due to defective capillary branching (Lu et al., 2004). The overall role of netrins in angiogenesis is controversial as studies demonstrate both proangiogenic and anti-angiogenic effects. Netrin-1 and netrin-4 have been proposed to exert pro-angiogenic effects through stimulating proliferation and migration in endothelial cells (Park et al., 2004; Wilson et al., 2006), with netrin-1 effects mediated by nitric oxide. In contrast, other reports indicate that netrins attenuate capillary sprouting via interaction with the UNC5B receptor (Lu et al., 2004).

\section{Slits and roundabouts}

The slits, secreted glycoproteins, and their roundabout (Robo) receptors are yet another family of ligands and receptors that function in both neuronal development and guidance as well as angiogenesis. Of the four known Robo receptors, Robo1 has been identified in a number of cell types including endothelial cells, whereas Robo4 (also known as magic Roundabout) appears to be exclusively expressed by vascular endothelium (Huminiecki and Bicknell, 2000). The effect of Slit-Robo interactions on angiogenesis is controversial with reports that suggest both pro-angiogenic and anti-angiogenic responses in Slit-treated endothelial cells. Through an interaction with Robo1, Slit2 promoted endothelial tube formation in vitro. Also, Slit2 levels were determined to be elevated in human tumors (Ahmed and Bicknell, 2009; Park et al., 2003; Wang et al., 2003). Genetic models of mice and zebrafish have been used to elucidate the role of Robo4 in angiogenesis. RNA interference of Robo4 in zebrafish resulted in defective vascular sprouting and patterning (Bedell et al., 2005) and administration of soluble Robo4 inhibited endothelial proliferation and migration in vitroand inhibited angiogenesis in an in vivo murine model (Suchting et al., 2005).

\section{Sprouty}

The sprouty family of proteins, including four sprouty proteins (spry 1-4) and four sprouty-related proteins (spred) that contain the conserved sprouty-related domain (SPR) also regulate angiogenesis (Cabrita and Christofori, 2008). Spry proteins modulate receptor tyrosine kinase (RTK) signaling. These proteins are activated by growth factor signaling cascades; VEGF and FGF signaling result 
in phosphorylation of spry proteins. Upon activation, spry proteins undergo nuclear translocation where they inhibit the MAPK pathway, establishing a negative feedback loop. Spry1 and Spry2 appear to attenuate FGF and VEGF-induced MAPK signaling (Impagnatiello MA, 2001). Spry4 has been shown to interact with Raf1, inhibiting VEGF-induced MAPK signaling (Sasaki et al., 2003).

\section{Vessel maturation}

Stabilization of the nascent capillary is critical for proper vessel function and integrity, and includes mural cell (pericytes and smooth muscle cells) association with the ablumenal capillary surface. Incomplete stabilization can result in hyperpermeable vessels leading to edema or, in the case of tumor vessels, increased incidence of metastasis. As with regulation of angiogenesis, several growth factors appear to function in vessel maturation.

\section{Platelet derived growth factor}

Platelet-derived growth factor (PDGF) is a major effector in facilitating vessel wall maturation. The PDGF family consists of four different isoforms (PDGFA, PDGFB, PDGFC and PDGFD) that form homodimers or a PDGF-AB heterodimer. Receptors for PDGFs include PDFGR $\alpha$ and PDGFR $\beta$, both tyrosine kinase receptors. PDGF-B, secreted by proliferating endothelial cells, binds to its receptor, PDGFR $\beta$, which is expressed by local undifferentiated mesenchymal cells to recruit them to the vessels. Mice lacking PDGFB or PDGFR $\beta$ display a profound decrease in the number of smooth muscle cells and pericytes associated with vessels, leading to edema and embryonic death (Hellstrom et al., 1999). In addition, VEGF-A levels are elevated in the mutant embryos, likely contributing to further edema (Hellstrom et al., 2001). The expression of PDFG has been shown to be the highest in tip cells, where secretion would establish a gradient of PDGF allowing for efficient pericyte recruitment (Gerhardt et al., 2003).

\section{The angiopoietins and Tie receptors}

Signaling through the Tie receptors, Tie1 and Tie2, functions to increase vessel stability. Tie1 and Tie2 are tyrosine kinase receptors that are expressed throughout the vasculature. Of the two receptors, there is a greater understanding of the role of Tie2. Angiopoietins, four secreted glycoproteins, function as ligands for the Tie2 receptor. The binding of angiopoietins 1 (Ang1) and 4 (Ang4) to Tie2 leads to receptor phosphorylation and signaling, whereas angiogpoietins 2 (Ang2) and 3 (Ang3) induce weak activation and are therefore thought to function as receptor antagonists (Maisonpierre et al., 1997; Valenzuela et al., 1999).

The angiopoietin/Tie2 signaling cascade has been shown to be important in mural cell recruitment to nascent vessels. Ang1 is secreted by pericytes and smooth muscle cells and thought to interact with Tie2 on endothelial cells, facilitating the interaction of the two cell types (Sato et al., 1995; Suri et al., 1996). In contrast, Ang2 production by the endothelium destabilizes the interaction and is associated with vessel proliferation.

Embryos lacking Tie2 die early in embryogenesis, between E9.5 and E10.5. Though the primary vascular plexi in these embryos appears unaffected, there is defective vascular remodeling and mural cell coverage that results in edema and hemorrhage (Dumont et al., 1994; Sato et al., 1995; Suri et al., 1996). This is phenocopied in embryos deficient in Ang1 as well as embryos overexpressing
Ang2 (Davis et al., 1996). Ang1 overexpression results in hypervascularization where numerous small stable vessels form.

The effects of the angiopoietin-Tie2 signaling pathway are modified by VEGF. In the presence of VEGF Ang2 stimulates angiogenesis, whereas in the absence of VEGF vessels regress (Maisonpierre et al., 1997). As mural cells disassociate from vessels and undergo apoptosis, the underlying endothelial cells are more readily able to respond to VEGF, which stimulates angiogenesis (Holash et al., 1999; Karamysheva, 2008).

\section{Hypoxic regulation of angiogenesis}

The vascular system begins to form well in advance of the developing embryo's requirement for blood flow; the primary vascular plexus is established as the embryo continues to be oxygenated through diffusion, indicating that the organism has evolved to avoid oxygen deficiency. However, hypoxia commonly occurs in physiological and pathological conditions and also drives angiogenesis. For instance, tumors up to $1 \mathrm{~mm}^{3}$ can be oxygenated solely through diffusion, but to grow beyond this size, a vasculature is required. It has been demonstrated that hypoxia is at least one of the stimuli that drives tumor angiogenesis. Accordingly, the molecular mechanisms underlying hypoxia-driven angiogenesis have been the subject of intense interest and are well understood.

\section{Hypoxia-inducible factor}

Hypoxia-inducible factor (HIF) is a transcription factor composed of two subunits, a constitutively active HIF-1 $\beta$ subunit and an oxygen-sensitive HIF $1 \alpha$ subunit. Under normoxia, HIF-1 $\alpha$ is synthesized and degraded whereas hypoxia leads to the accumulation of HIF- $1 \alpha$. HIF- $1 \alpha$ dimerizes with HIF-1 $\beta$ and binds DNA to activate transcription of a number of target genes including many factors involved in the regulation of angiogenesis such as VEGF, PLGF, Ang1, Ang2 and PDGF (Kelly et al., 2003).

In normoxic conditions, the von Hipple-Lindau tumor suppressor protein $(\mathrm{VHL})$ recruits a complex containing ubiquitin ligase to HIF-1 $\alpha$ (Salceda and Caro, 1997). Binding of VHL to HIF-1 $\alpha$ is mediated by hydroxylation of proline residues, a reaction that depends on oxygen (Ivan et al., 2001; Jaakkola et al., 2001). When oxygen is abundant, VHL is hydroxylated, and VHL mediated ubiquitination causes the degradation of HIF-1 $\alpha$. Under hypoxic conditions, VHL hydroxylation is inhibited and $\mathrm{HIF}-1 \alpha$ accumulates. HIF- $1 \alpha$ itself is also subject to oxygen dependent hydroxylation (Peet and Linke, 2006). Hydroxylation of HIF-1 $\alpha$ prevents its interaction with transcriptional co-activators including $\mathrm{p} 300$ and CBP (Semenza, 2007).

Genetic studies have revealed the requirement for HIF-1 $\alpha$ in embryonic vascular development. HIF- $1 \alpha-/-$ embryos die during mid-gestation and display abnormal embryonic and yolk sac vasculatures (lyer et al., 1998). Overexpression of HIF-1 $\alpha$ induces vascularization without increased vessel permeability in contrast to VEGF overexpression, which induces tortuous and hyperpermeable vessel growth (Detmar et al., 1998; Springer et al., 1998). This suggests that HIF- $1 \alpha$ also regulates genes that are involved in vessel stability. Accordingly, overexpression of HIF-1 $\alpha$ in the retina results in significant neovascularization and concomitant increases in VEGF, PLGF, Ang1, Ang2 and PDGF mRNA (Kelly et al., 2003). $\mathrm{HIF}-1 \alpha$ also induces expression of stromal cell derived factor-1 (SDF-1), which functions to mobilize endothelial cell precursors in the bone marrow (Ramirez-Bergeron et al., 2006). 


\section{Arterial and venous specification}

\section{Ephrins and Ephs}

The specification of arteries and veins is thought to occur even before the formation of blood vessels themselves and has been attributed to the differential expression of the ephrin family of proteins and their receptors, Ephs. The endothelium of developing arteries express ephrinB2 while its receptor, EphB4, is restricted to the endothelium of developing veins (Wang et al., 1998). Ephrin B2 and EphB4 appear to be necessary for proper vascular development as mice lacking either of these proteins die as embryos (E10.5) and display defects in vascular patterning in both the yolk sac and within the embryo itself (Gerety et al., 1999; Wang et al., 1998). Ephrins also appear to influence the arteriovenous anastomoses by inhibiting VEGF and Ang1 endothelial cell stimulation (Gerety et al., 1999; Wang et al., 1998).

Other proteins that are differentially expressed in arteries and veins include the neuropilins and members of the Notch family (Ribatti et al., 2009). Neuropilin-1 is expressed in arterial endothelium and neuropilin-2 is expressed in venous endothelium early in embryonic vasculogenesis, well before the onset of blood flow (Herzog et al., 2005). The Notch family members restricted to the arterial system include Notch 3, DDL4 and GRIDLOCK. Roles for Notch in remodeling of the primary vascular plexus and maintenance of differentiated arteries have been described (Hirashima, 2009).

\section{Conclusions}

Abnormal vessel development is central to a number of diseases such as cancer, psoriasis, rheumatoid arthritis, age-related vision loss (including diabetic retinopathy and age-related macular degeneration), ulcers, cardiovascular disease and stroke. A host of anti-angiogenic therapeutics is currently FDA-approved and used for treatment of cancers, vision loss and other diseases. In addition, numerous therapeutic angiogenesis agents, aimed at stimulating angiogenesis, are being developed for use in the clinic.

It is clear that the molecular signaling that occurs in vasculogenesis and angiogenesis is both complex and diverse. Precise coordination of these signals in multiple cell types is critical for appropriate vascular development and function. The need for additional research into the signaling pathways involved in vasculogenesis and developmental angiogenesis is clear. Not only will such research further our mechanistic knowledge of vessel formation and development, but it will also have practical applications to human disease and pathological states.

\section{References}

AASE, K., VON EUleR, G., LI, X., PONTEN, A., THOREN, P., CAO, R., CAO, Y., OLOFSSON, B., GEBRE-MEDHIN, S., PEKNY, M. et al. (2001). Vascular endothelial growth factor-B-deficient mice display an atrial conduction defect. Circulation 104: 358-364.

AHMED, Z. and BICKNELL, R. (2009). Angiogenic signalling pathways. Methods Mol Biol. 467: 3-24.

ASAHARA, T., MUROHARA, T., SULLIVAN, A., SILVER, M., VAN DER ZEE, R., LI, T., WITZENBICHLER, B., SCHATTEMAN, G. and ISNER, J.M. (1997). Isolation of putative progenitor endothelial cells for angiogenesis. Science 275: 964-967.

AZUMA, H. (2000). Genetic and molecular pathogenesis of hereditary hemorrhagic telangiectasia. J Med Invest. 47: 81-90.

BAIRD, A. and DURKIN, T. (1986). Inhibition of endothelial cell proliferation by type beta-transforming growth factor: interations with acidic and basic fibroblast growth factors. Biochem. Biophys. Res. Commun. 138: 476-482.

BANU, N., TEICHMAN, J., DUNLAP-BROWN, M., VILLEGAS, G. and A., T. (2006) Semaphorin $3 C$ regulates endothelial cell function by increasing integrin activity. FASEB J. 20: 2150-2152.

BARBARA, N.P., WRANA, J.L. and LETARTE, M. (1999). Endoglin is an accessory protein that interacts with the signaling receptor complex of multiple members of the transforming growth factor-beta superfamily. J Biol Chem. 274: 584-594.

BATES, D.O., CUI, T.G., DOUGHTY, J.M., WINKLER, M., SUGIONO, M., SHIELDS, J.D., PEAT, D., GILLATT, D. and HARPER, S.J. (2002). VEGF165b, an inhibitory splice variant of vascular endothelial growth factor, is down-regulated in renal cell carcinoma. Cancer Res 62.

BEDELL, V.M., YEO, S.Y., PARK, K.W., CHUNG, J., SETH, P., SHIVALINGAPPA, V., ZHAO, J., OBARA, T., SUKHATME, V.P., DRUMMOND, I.A. et al. (2005). roundabout4 is essential for angiogenesis in vivo. Proc Natl Acad Sci USA 102: 6373-6378.

BEENKEN, A. and MOHAMMADI, M. (2009). The FGF family: biology, pathophysiology and therapy. Nat Rev Drug Discov. 8: 235-253.

BELLOMO, D., HEADRICK, J.P., SILINS, G.U., PATERSON, C.A., THOMAS, P.S., GARTSIDE, M., MOULD, A., CAHILL, M.M., TONKS, I.D., GRIMMOND, S.M. et al. (2000). Mice lacking the vascular endothelial growth factor-B gene (Vegfb) have smaller hearts, dysfunctional coronary vasculature, and impaired recovery from cardiac ischaemia. Circ Res. 86: E29-E35.

BENEDITO, R., ROCA, C., SORENSEN, I., ADAMS, S., GOSSLER, A., FRUTTIGER, M. and ADAMS, R.H. (2009). The notch ligands DII4 and Jagged1 have opposing effects on angiogenesis. Cell 137: 1124-1135.

BIELENBERG, D.R., HIDA, Y., SHIMIZU, A., KAIPAINEN, A., KREUTER, M., KIM, C.C. and KLAGSBRUN, M. (2004). Semaphorin 3F, a chemorepulsant for endothelial cells, induces a poorly vascularized, encapsulated, nonmetastatic tumor phenotype. J Clin Invest. 114: 1260-1271.

BRAMBILLA, E., CONSTANTIN, B., DRABKIN, H. and ROCHE, J. (2000). Semaphorin SEMA3F localization in malignant human lung and cell lines: A suggested role in cell adhesion and cell migration. Am J Pathol. 156: 939-950.

BYRD, N., BECKER, S., MAYE, P., NARASIMHAIAH, R., ST-JACQUES, B., ZHANG, X., MCMAHON, J., MCMAHON, A.P. and GRABEL, L. (2002). Hedgehog is required for murine yolk sac angiogeneis. Development 129: 361-372.

CABRITA, M.A. and CHRISTOFORI, G. (2008). Sprouty proteins, masterminds of receptor tyrosine kinase signaling. Angiogenesis 11: 53-62.

CAO, Y., LINDEN, R., FARNEBO, J., CAO, R., ERIKSSON, A., KUMAR, V., QI, J.H., CLAESSON-WELSH, L. and ALITALO, K. (1998). Vascular endothelial growth factor C induces angiogenesis in vivo. Proc Natl Acad Sci USA 95: 14389-14394.

CAPPARUCCIA, L. and TAMAGNONE, L. (2009). Semaphorin signaling in cancer cells and in cells of the tumor microenvironment - two sides of a coin. $J \mathrm{Cell} S \mathrm{SC}$ 122: $1723-1736$.

CAPRIOLI, A., MINKO, K., DREVON, C., EICHMANN, A., DIETERLEN-LIEVRE, F. and JAFFREDO, T. (2001). Hemangioblast commitment in the avian allantois: cellular and molecular aspects. Dev Biol 238: 64-78.

CARMELIET, P., FERREIRA, V., BREIER, G., POLLEFEYT, S., KIECKENS, L., GERTSENSTEIN, M., FAHRIG, M., VANDENHOECK, A., HARPALL, K., EBERHARDT, C. et al. (1996). Abnormal blood vessel development and lethality in embryos lacking a single VEGF allele. Nature 380: 435-439.

CARMELIET, P., MOONS, L., LUTTUN, A., VINCENTI, V., COMPERNOLLE, V., DE MOL, M., WU, Y., BONO, F., DEVY, L., BECK, H. et al. (2001). Synergism between vascular endothelial growth factor and placental growth factor contributes to angiogenesis and plasma extravasation in pathological conditions. Nat Med7:575-583.

CHEN, H., BAGRI, A., ZUPICICH, J., ZOU, Y., STOECKLI, E., PLEASURE, S., LOWENSTEIN, D., SKARNES, W., CHEDOTAL, A. and TESSIER-LAVIGNE, M. (2000). Neuropilin-2 regulates the development of select cranial and sensory nerves and hippocampal mossy fiber projections. Neuron 25: 43-56.

CHEN, Y.G., HATA, A., LO, R.S., WOTTON, D., SHI, Y., PAVIETICH, M. and MASSAGUE, J. (1998). Determinants of specificity in TGF-beta signal transduction. Genes Dev. 12: 2144-2152.

CHOI, K., KENNEDY, M., KAZAROV, A., PAPADIMITRIOU, J.C. and KELLER, G. (1998). A common precursor for hematopoietic and endothelial cells. Development 125: 725-732.

COX, C.M. and POOLE, T.J. (2000). Angioblast differentiation is influenced by the 
local environment: FGF-2 induces angioblasts and patterns vessel formation in the quail embryo. Dev Dyn 18: 371-382.

DAVIS, S., ALDRICH, T.H., JONES, P.F., ACHESON, A., COMPTON, D., JAIN, V., RYAN, T.E., BRUNO, J., RADZIEJEWSKI, C., MAISONPIERRE, P.C. et al. (1996). Isolation of angiopoietin-1, a ligand for the TIE2 receptor, by secretion-trap expression cloning. Cell 87: 1161-1169.

DAYANIR, V., MEYER, R.D., LASHKARI, K. and RAHIMI, N. (2001). Identification of tyrosine residues in vascular endothelial growth factor receptor-2/FLK-1 involved in activation of phosphatidylinositol 3-kinase and cell proliferation. J Biol Chem 276: 17686-17692.

DETMAR, M., BROWN, L.F., SCHON, M.P., ELICKER, B.M., VELASCO, B., RICHARD, L., FUKUMURA, D., MONSKY, W., CLAFFEY, K.P. and JAIN, R.K. (1998). Increased microvascular density and enhanced leukocyte rolling and adhesion in the skin of VEGF transgenic mice. J Invest Dermatol. 111: 1-6.

DICKSON, M.C., MARTIN, J.S., COUSINS, F.M., KULKARNI, A.B., KARLSSON, S. and AKHURST, R.J. (1995). Defective haematopoiesis and vasculogenesis in transforming growth factor-beta 1 knock out mice. Development 121: 1845-1854.

DJONOV, V., KURZ, H. and BURRI, P.H. (2002). Optimality in the developing vascular system: branching remodeling by means of intussusception as an effective adaptation mechanism. Dev Dyn 224: 391-402.

DJONOV, V., SCHMID, M., TSCHANZ, S.A. and BURRI, P.H. (2000). Intussusceptive angiogenesis: its role in embryonic vascular network formation. Circ Res. 86: 286-292.

DUMONT, D.J., GRADWOHL, G., FONG, G.H., PURI, M.C., GERTSENSTEIN, M., AUERBACH, A. and BREITMAN, M.L. (1994). Dominant-negative and targeted null mutations in the endothelial receptor tyrosine kinase, tek, reveal a critical role in vasculogenesis of the embryo. Genes Dev. 8: 1897-1909.

DYER, M.A., FARRINGTON, S.M., MOHN, D., MUNDAY, J.R. and BARON, M.H. (2001). Indian hedgehog activated hematopoiesis and vasculogenesis and can rectify neurectodermal cell fate in the mouse embryo. Development 128: 1717-30.

EICHMANN, A., CORBEL, C., NATAF, V., VAIGOT, P., BREANT, C. and LEDOUARIN, N.M. (1997). Ligand-dependent development of the endothelial and hemopoietic linages from embryonic mesodermal cells expressing vascular endothelial growth factor receptor 2. Proc Natl Acad Sci USA 94: 5141-5416.

FERRARA, N., CARVER-MOORE, K., CHEN, H., DOWD, M., LU, L., O'SHEA, K.S., POWELL-BRAXTON, L., HILLAN, K.J. and MOORE, M.W. (1996). Heterozygous embryonic lethality induced by targeted inactivation of the VEGF gene. Nature 380: 439-442

FOLKMAN, J. (1971). Tumor angiogenesis: therapeutic implications. N Engl J Med 285: 1182-6.

FONG, G.H., ROSSANT, J., GERTSENSTEIN, M. and BREITMAN, M.L. (1995). Role of the Flit-1 receptor tyrosine kinase in regulating the assembly of vascular endothelium. Nature 376: 66-70.

FRATER-SCHRODER, M., MULLER, G. and BIRCHMEIER, W. (1986). Transforming growth factor-beta inhibits endothelial cell proliferation. Biochem. Biophys. Res. Commun. 137: 295-302.

FUJIO, Y. and WALSH, K. (1999). Akt mediate cytoprotection of endothelial cells by vascular endothelial growth factor in an anchorage-dependent manner. $J$ Biol Chem 274: 16349-16354.

FUKUMURA, D., GOHONGI, T., KADAMBI, A., IZUMI, Y., ANG, J., YUN, C.O., BUERK, D.G., HUANG, P.L. and JAIN, R.K. (2001). Predominant role of endothelial nitric oxide synthase in vascular endothelial growth factor-induced angiogenesis and vascular permeability. Proc Natl Acad Sci USA 98: 2604-2609.

GAUR, P., BIELENBERG, D.R., SAMUEL, S., BOSE, D., ZHOU, Y., GRAY, M.J., DALLAS, N.A., FAN, F., XIA, L., LU, J. et al. (2009). Role of class 3 semaphorins and their receptors in tumor growth and angiogenesis. Clin Cancer Res 15:6763-6770.

GAVARD, J. and GUTKIND, J.S. (2006). VEGF controls endothelial-cell permeability by promoting the beta-arrestin-dependent endocytosis of VE-cadherin. Nat Cell Biol. 8: 1223-1234.

GERETY, S.S., WANG, H.U., CHEN, Z.F. and ANDERSON, D.J. (1999). Symmetrical mutant phenotypes of the receptor EphB4 and its specific transmembrane ligand ephrin-B2 in cardiovascular development. Mol Cell. 4: 403-414.

GERHARDT, D., GOLDING, M., FRUTTIGER, M., RUHRBERG, C., LUNDKVIST, A., AMBRAMSSON, A., JELTSCH, M., MITCHELL, C., ALITALO, K., SHIMA, D. et al. (2003). VEGF guides angiogenic sprouting utilizing endothelial tip cell filopodia. J Cell Biol 161: 1163-1177.
GIGER, R.J., CLOUTIER, J.F., SAHAY, A., PRINJHA, R.K., LEVENGOOD, D.V., MOORE, S.E., PICKERING, S., SIMMONS, D., RASTAN, S., WALSH, F.S. et al. (2000). Neuropilin-2 is required in vivo for selective axon guidance responses to secreted semaphorins. Neuron 25: 29-41.

GOUMANS, M.J. and MUMMERY, C. (2000). Functional analysis of the TGFbeta receptor/Smad pathway through gene ablation in mice. Int J Dev Bio/ 44: 253-265.

GU, C., YOSHIDA, Y., LIVET, J., REIMERT, D.V., MANN, F., MERTE, J., HENDERSON, C.E., JESSELL, T.M., KOLODKIN, A.L. and GINTY, D.D. (2005). Semaphorin $3 \mathrm{E}$ and plexin-D1 control vascular pattern independently of neuropilins. Science 307: 265-268.

GUTTMANN-RAVIV N, S.-H.N., VARSHAVSKY A, GUIMARAES-STERNBERG C, KESSLER O, NEUFELD G. (2007). Semaphorin-3A and semaphorin-3F work together to repel endothelial cells and to inhibit their survival by induction of apoptosis. J Biol Chem. 282: 26294-26305.

HELLSTROM, M., GERHARDT, H., KALEN, M., LI, X., ERIKSSON, U. and WOLBURH, H. (2001). Lack of pericytes leads to endothelial hyperplasia and abnorma vascular morphogenesis. J Cell Biol 153: 543-553.

HELLSTROM, M., KALEN, M., LINDAHL, P., ABRAMSON, A. and BETSCHOLTZ, C. (1999). Role of PDGF-B and PDGFR-beta in recruitment of vascular smooth muscle cells and pericytes during embryonic blood vessel formation in the mouse. Development 126: 3047-3055.

HERZOG, Y., GUTTMANN-RAVIV, N. and NEUFELD, G. (2005). Segregation of arterial and venous markers in subpopulations of blood islands before vessel formation. Dev Dyn. 232: 1047-1055.

HIRASHIMA, M. (2009). Regulation of endothelial cell differentiation and arterial specification by VEGF and Notch signaling. Anat Sci Int. 84: 95-101.

HIS, W. (1900). Lecithoblast und Angioblast der Wirbelthiere. Abhandl. K.S. Ges. Wis. Math.-Phys. 22: 171-328.

HOFER, E. and SCHWEIGHOFER, B. (2007). Signal transduction induced in endothelial cells by growth factor receptors involved in angiogenesis. Thromb Haemost. 97: 355-63.

HOLASH, J., WEIGAND, S.J. and YANCOPOULOS, G.D. (1999). New model of tumor angiogenesis: dynamic balance between vessel regression and growth mediated by angiopoietins and VEGF. Oncogene 18: 5356-62.

HOLMQVIST, K., CROSS, M.J., ROLNEY, C., HAGERKVIST, R., RAHIMI, N., MATSUMOTO, T., CLAESSON-WELSH, L. and WELSH, M. (2004). The adaptor protein shb bind to tyrosine 1175 in vacular endothelial growth factor (VEGF) receptor-2 and regulates VEGF-dependent cellular migration. J Biol Chem 279:22267-22275.

HOODLESS, P.A. and WRANA, J.L. (1998). Mechanism and function of signaling by the TGF beta superfamily. Curr. Top. Microbiol. Immunol. 228: 235-272.

HRABE DE ANGELIS, M., MCINTYRE, J.N. and GOSSLER, A. (1997). Maintenance of somite borders in mice requires the Delta homologue DIl1. Nature717-21.

HUMINIECKI, L. and BICKNELL, R. (2000). In silico cloning of novel endothelialspecific genes. Genome Res. 10: 1796-1806

IMPAGNATIELLOMA, W.S., GANNONG, COMPAGNIA, COTTENM, CHRISTOFOR G. (2001). Mammalian sprouty-1 and -2 are membrane-anchored phosphoprotein inhibitors of growth factor signaling in endothelial cells. J Cell Biol. 152: 1087-1098.

IRUELA-ARISPE, M.L. and SAGE, E.H. (1993). Endothelial cells exhibiting engiogenesis in vitro proliferate in response to TGF-beta. J. Cell. Biochem. 52: 414-430.

IVAN, M., KONDO, K., YANGE, H., KIM, W., VALIANDO, J., OHH, M., SALIC, A., ASARA, J.M., LANE, W.S. and KAELIN, W.G.J. (2001). HIFalpha targeted fo VHL-mediated destruction by proline hydroxylation: Implications for $\mathrm{O} 2$ sensing. Science 292: 464-468

IYER, N.V., KOTCH, L.E., AGANI, F., LEUNG, S.W., LAUGHNER, E., WENGER, R.H., GASSMANN, M., GEARHART, J.D., LAWLER, A.M., YU, A.Y. et al. (1998). Cellular and developmental control of $\mathrm{O} 2$ homeostasis by hypoxia-inducible factor 1 alpha. Genes Dev. 12: 149-162.

JAAKKOLA, P., MOLE, D.R., TIAN, Y.M., WILSON, M.I., GIELBERT, J., GASKELL, S.J., KRIEGSHEIM, A.V., HEBESTREIT, H.F., MUKERJI, M., SCHOFIELD, C.J. et al. (2001). Targeting of HIFalpha to the von Hipple-Lindau ubiquitylation complex by O2-regulated prolyl hydroxylation. Science 929: 468-472.

JAKOBSSON, L., BENTLEY, K. and GERHARDT, H. (2009). VEGFRs and Notch: a dynamic collaboration in vascular patterning. Biochem. Soc. Trans. 37:1233-1236.

JENKINS, D. (2009). Hedgehog signalling: emerging evidence for non-canonical pathways. Cell Signal. 21: 1023-1034 
KARAMYSHEVA, A.F. (2008). Mechanisms of angiogenesis. Biochemistry (Mosc) 73: 751-762.

KARKKAINEN, M.J., HAIKO, P., SAINIO, K., PARTANEN, J., TAIPALE, J., PETROVA, T.V., JELTSCH, M., JACKSON, D.G., TALIKKA, M., RAUVALA, H. et al. (2003). Vascular endothelial growth factor $C$ is required for sprouting of the first lymphatic vessels from embryonic veins. Nature Immunology 5: 74-80.

KAWASAKI, T., KITSUKAWA, T., BEKKU, Y., MATSUDA, Y., SANBO, M., YAGI, T. and FUJISAWA, H. (1999). A requirement for neuropilin-1 in embryonic vessel formation. Development 126: 4895-4902.

KELLY, B.D., HACKETT, S.F., HIROTA, K., OSHIMA, Y., CAI, Z., BERG-DIXON, S., ROWAN, A., YAN, Z., CAMPOCHIARO, P.A. and SEMENZA, G.L. (2003). Cell type-specific regulation of angiogenic growth factor gene expression and induction of angiogenesis in nonischemic tissue by a constitutively active form of hypoxia-inducible factor 1. Circ Res. 93: 1074-1081.

KENDALL, R.L., RUTLEdGE, R.Z., MAO, X., TEBBEN, A.J., HUNGATE, R.W. and THOMAS, K.A. (1999). Vascular endothelial growth factor receptor KDR tyrosine kinase activity is increased by autophosphorylation of two activation loop tyrosine residues. J Biol Chem. 274: 6453-6460.

KESSLER, O., SHRAGA-HELED, N., LANGE, T., GUTMANN-RAVIV, N., SABO, E., BARUCH, L., MACHLUF, M. and NEUFELD, G. (2004). Semaphorin-3F is an inhibitor of tumor angiogenesis. Cancer Res 64: 1008-1015.

KEYT, B.A., BERLEAU, L.T., NGUYEN, H.V., CHEN, H., HEINSOHN, H., VANDLEN, R. and FERRARA, N. (1996). The carboxyl-terminal domain (111-165) of vascular endothelial growth factor is critical for its mitogenic potency. J Biol Chem. 271: 7788-7795.

KIGEL, B., VARSHAVSKY, A., KESSLER, O. and NEUFELD, G. (2008). Successful inhibition of tumor development by specific class-3 semaphorins is associated with expression of appropriate semaphorin receptors by tumor cells. PLos One. 3: e3287.

KOWANETZ, M. and FERRARA, N. (2006). Vascular endothelial growth factor signaling pathways: therapeutic perspective. Clin Cancer Res 12: 5018-5022.

KREBS, L.T. (2000). Notch signaling is essential for vascular morphogenesis in mice. Genes Dev 14: 1343-1352.

KREBS, L.T., SHUTTER, J.R., TANIGAKI, K., HONJO, T., STARK, K.L. and GRIDLEY, T. (2004). Haploinsufficient lethality and formation of arteriovenous malformations in Notch pathway mutants. Genes Dev 18: 2469-2473.

LAMALICE, L., HOULE, F., JOURDAN, G. and HUOT, J. (2004). Phosphorylation of tyrosine 1214 on VEGFR2 is required for VEGF-induced activation of Cdc42 upstream of SAPK2/p38. Oncogene 23: 434-445.

LARSSON, J., GOUMANS, M.J., SJOSTRAND, L.J., VAN ROOIJEN, M.A., WARD, D., LEVEEN, P., XU, X., TEN DIJKE, P., MUMMERY, C.L. and KARLSSON, S. (2001). Abnormal angiogenesis but intact hematopoietic potential in TGF-beta type I receptor-deficient mice. EMBO J. 20: 1663-1673.

LECOUTER, J., KOWALSKI, J., FOSTER, J., HASS, P., ZHANG, Z., DILLARDTELM, L., FRANTZ, G., RANGELL, L., DEGUZMAN, L., KELLER, G.A. et al. (2001). Identification of an angiogenic mi- togen selective for endocrine gland endothelium. Nature 412: 877-884.

LETAMENDIA, A., LASTRES, P., BOTELLA, L.M., RAAB, U., LANGA, C., VELASCO, B., ATTISANO, L. and BERNABEU, C. (1998). Role of endoglin in cellular responses to transforming growth factor-beta. A comparative study with betaglycan. J Biol Chem. 273: 33011-33019.

LETTERIO, J.J., GEISER, A.G., KULKARNI, A.B., ROCHE, N.S., SPORN, M.B. and ROBERTS, A.B. (1994). Maternal rescue of transforming growth factor-beta 1 null mice. Science 264: 1936-1938.

LI, C., GUO, B., BERNABEU, C. and KUMAR, S. (2001). Angiogenesis in breast cancer: the role of transforming growth factor beta and CD105. Microsc. Res. Tech. 52: 437-449.

LI, D.Y., SORENSEN, L.K., BROOKE, B.S., URNESS, L.D., DAVIS, E.C., TAYLOR, D.G., BOAK, B.B. and WENDEL, D.P. (1999). Defective angiogenesis in mice lacking endoglin. Science 284: 1534-1537.

LIU, Z., SHIRAKAWA, T., LI, Y., SOMA, A., OKA, M., DOTTO, G.P., FAIRMAN, R.M., VELAZQUEZ, O.C. and HERLYN, M. (2003). Regulation of Notch1 and DIl4 by vascular endothelial growth factor in arterial endothelial cells: implications for modulating arteriogenesis and angiogenesis. Mol Cell Biol 23: 12-25.

LOBOV, I.B., RENARD, R.A., PAPADOPOULOS, N., GALE, N.W., THURSTON, G., YANCOPOULOS, G.D. and WIEGAND, S.J. (2007). Delta-like ligand 4 (DII4) is induced by VEGF as a negative regulator of angiogenic sprouting. Proc Natl Acad
Sci USA 104: 3219-3224.

LU, X., LE NOBLE, F., YUAN, L., JIANG, Q., DE LAFARGE, B., SUGIYAMA, D., BRÉANT, C., CLAES, F., DE SMET, F., THOMAS, J.L. et al. (2004). The netrin receptor UNC5B mediates guidance events controlling morphogenesis of the vascular system. Nature 432: 179-186.

LYTTLE, D.J., FRASER, K.M., FLEMING, S.B., MERCER, A.A. and ROBINSON, A.J. (1994). Homologs of vascular endothelial growth factor are encoded by the poxvirus orf virus. J. Virol. 68: 84-92.

MAGLIONE, D., GUERRIERO, V., VIGLIETTO, G., DELLI-BOVI, P. and PERISCO, M.G. (1991). Isolation of a human placenta cDNA coding for a protein related to the vascular permeability factor. Proc Natl Acad Sci USA 88: 9267-9271.

MAISONPIERRE, P.C., SURI, C., JONES, P.F., BARTUNKOVA, S., WEIGAND, S.J., RADZIEJEWSKI, C., COMPTON, D., MCCLAIN, J., ALDRICH, T.H., PAPADOPOULOS, N. et al. (1997). Angiopoietin-2, a natural antagonist for Tie2 that disrupts in vivo angiogenesis. Science 277: 55-60.

MAKANYA, A.N., HLUSHCHUK, R. and DJONOV, V. (2009). Intussusceptive angiogenesis and its role in vascular morphogenesis, patterning, and remodeling. Angiogenesis 12: 113-123.

MATSUMOTO, T., BOHMAN, S., DIXELIUS, J., BERGE, T., DIMBERG, A., MAGNUSSON, P., WANG, L., WIKNER, C., QI, J.H., WERNSTEDT, C. et al. (2005). VEGF receptor-s Y951 signaling and a role for the adapter molecule TSAd in tumor angiogenesis. EMBO J. 24: 2342-2353.

MECHTCHERIAKOVA, D., SCHABBAUER, G., LUCERNA, M., CLAUSS, M., DE MARTIN, R., BINDER, B.R. and HOFER, E. (2001). Specificity, diversity, and convergence in VEGF and TNF-alpha signaling events leading to tissue factor up-regulation via EGR-1 in endothelial cells. FASEB J. 15: 230-424.

MECHTCHERIAKOVA, D., WLACHOS, A., HOLZMULLER, H., BINDER, B.R. and HOFER, E. (1999). Vascular endothelial cell growth factor-induced tissue factor expression in endothelial cells is mediated by EGR-1. Blood 93: 3811-3823.

MIAO, H.Q., SOKER, S., FEINER, L., ALONSO, J.L., RAPER, J.A. and KLAGSBRUN, M. (1999). Neuropilin-1 mediates collapsin-1/semaphorin III inhibition of endothelial cell motility: functional competition of collapsin-1 and vascular endothelial growth factor-165. J. Cell Biol. 146: 233-242.

NAGASE, M., NAGASE, T., KOSHIMA, I. and FUJITA, T. (2006). Critical time window of hedgehog-dependent angiogenesis in murine yolk sac. Microvasc Res 71:85-90.

OLSSON, A.K., DIMBERG, A., KREUGER, J. and CLAESSON-WELSH, L. (2006). VEGF receptor signaling in control of vascular function. Nat Rev Mol Cell Biol 7: 359-371.

OSHIMA, M., OSHIMA, H. and TAKETO, M.M. (1996). TGF-beta receptor type II deficiency results in defects of yolk sac hematopoiesis and vasculogenesis. Dev Biol 179: 297-302.

PARDANAUD, L. and DIETERLEN-LIEVRE, F. (1993). Emergence of endothelial and hemopoietic cells in the avian embryo. Anat Embryol (Berl) 187: 107-114.

PARK, K.W., CROUSE, D., LEE, M., KARNIK, S.K., SORENSEN, L.K., MURPHY, K.J., KUO, C.J. and LI, D.Y. (2004). The axonal attractant Netrin-1 is an angiogenic factor. Proc Natl Acad Sci USA 101: 16210-16215.

PARK, K.W., MORRISON, C.M., SORENSEN, L.K., JONES, C.A., RAO, Y., CHIEN, C.B., WU, J.Y., URNESS, L.D. and LI, D.Y. (2003). Robo4 is a vascular-specific receptor that inhibits endothelial migration. Dev Biol. 261: 251-267.

PATAN, S. (2000). Vasculogenesis and angiogenesis as mechanisms of vascular network formation, growth and remodeling. J. Neuroloncol 50: 1-15.

PEET, D. and LINKE, S. (2006). Regulation of HIF:Asparaginyl hydroxylation. Novartis Found Symp 272: 37-49.

RAMIREZ-BERGERON, D.L., RUNGE, A., ADELMAN, D.M., GOHIL, M. and SIMON, M.C. (2006). HIF-dependent hematopoietic factors regulate the development of the embryonic vasculature. Dev Cell 11: 81-92.

RAYCHAUDHURY, A. and D'AMORE, P.A. (1991). Endothelial cell regulation by transforming growth factor-beta. J. Cell. Biochem. 47: 224-229.

REAGAN, F.P. (1915). Vascularization phenomena in fragments of embryonic bodies completely isolated from yolk sac blastoderm. Anat Rec. 9: 329-341.

RIBATTI, D., NICO, B. and CRIVELLATO, E. (2009). Morphological and molecular aspects of physiological vascular morphogenesis. Angiogenesis 12: 101-111.

RIOBO, N.A., SAUCY, B., DILIZIO, C. and MANNING, D.R. (2006). Activation of heterotrimeric G proteins by Smoothened. Proc NatIAcad Sci USA 103: 12607-12612.

RISAU, W. and FLAMME, I. (1995). Vasculogenesis. Annu Rev Cell Dev Biol 11: 74-91. 
RISAU, W. and LEMMON, V. (1988). Changes in the vascular extracellular matrix during embryonic vasculogenesis and angiogenesis. Dev Biol 125: 441-450.

RISAU, W., SARIOLA, H., ZERWES, H.G., SASSE, J., EKBLOM, P., KEMLER, R. and DOETSCHMAN, T. (1988). Vasculogenesis and angiogenesis in embryonicstem-cell-derived embryoid bodies. Development 102: 471-478.

ROBERTS, A.B., SPORN, M.B., ASSOIAN, R.K., SMITH, J.M., ROCHE, N.S., WAKEFIELD, L.M., HEINE, U.I., LIOTTA, L.A., FALANGA, V., KEHRL, J.H. et al. (1986). Transforming growth factor type beta: rapid induction of fibrosis and angiogenesis in vivo and stimulation of collagen formation in vitro. Proc Natl Acad Sci USA 83: 4167-471.

ROCHE, J., BOLDOG, F., ROBINSON, M., ROBINSON, L., VARELLA-GARCIA, M., SWANTON, M., WAGGONER, B., FISHEL, R., FRANKLIN, W., GEMMILL, R. et al. (1996). Distinct 3p21.3 deletions in lung cancer and identification of a new human semaphorin. Oncogene 12: 1289-1297.

ROSSANT, J. and HOWARD, L. (2002). Signaling pathways in vascular development. Annu. Rev. Cell Dev. Biol. 18: 541-573.

SABIN, F.R. (1920). Studies on the origin of blood-vessels and of red blood-corpuscles as seen in the living blastoderm of chicks during the second day of incubation. Contrib Embryol 36: 213-259.

SALCEDA, S. and CARO, J. (1997). Hypoxia-inducible factor 1 alpha (HIF1alpha) protein is rapidly degraded by the ubiquitin-proteasome system under normoxic conditions. Its stabilization by hypoxia depends on redox-induced changes. J Biol Chem. 272: 22642-22647.

SASAKI, A., TAKETOMI, T., KATO, R., SAEKI, K., NONAMI, A., SASAKI, M., KURIYAMA, M., SAITO, N., SHIBUYA, M. and YOSHIMURA, A. (2003). Mammalian Sprouty4 suppresses Ras-independent ERK activation by binding to Raf1. Nat Cell Biol. 5: 427-432.

SATO, T.N., TOZAWA, Y., DEUTSCH, U., WOLBURG-BUCHHOLZ, K., FUJIWARA, Y., GENDRON-MAGUIRE, M., GRIDLEY, T., WOLBURG, H., RISAU, W. and QIN, Y. (1995). Distinct roles of the receptor tyrosine kinases Tie-1 and Tie-2 in blood vessel formation. Nature 376: 70-74.

SEMENZA, G.L. (2007). Vasculogenesis, angiogenesis, and arteriogenesis: mechanisms of blood vessel formation and remodeling. J Cell Biochem. 102: 840-847.

SENGER, D.R., CONNOLLY, D.T., VAN DE WATER, L., FEDER, J. and DVORAK, H.F. (1990). Purification and NH2-terminal amino acid sequece of guinea pig tumor-secreted vascular permeability factor. Cancer Res 15: 1774-1778.

SHALABY, F., HO, J., STANFORD, W.L., FISCHER, K.D., SCHUH, A.C., SCHWARZ, L., BERNSTEIN, A. and ROSSANT, J. (1997). A requirement for FIk1 in primitive and definitive hematopoiesis and vasculogenesis. Cell 89: 981-990.

SHALABY, F., ROSSANT, J., YAMAGUCHI, T.P., GERTSENSTEIN, M., WU, X.F., BREITMAN, M.L. and SCHUH, A.C. (1995). Failure of blood-island formation and vasculogenesis in Flk-1-deficient mice. Nature 376: 62-66.

SHAWBER, C.J., DAS, I., FRANCISCO, E. and KITAJEWSKI, J. (2003). Notch signaling in primary endothelial cells. Ann NY Acad Sci 995: 162-170.

SPRINGER, M.L., CHEN, A.S., KRAFT, P.E., BEDNARSKI, M. and BLAU, H.M. (1998). VEGF gene delivery to muscle: potential role for vasculogenesis in adults. Mol Cell 2: 549-558.

SUCHTING, S., FREITAS, C., LE NOBLE, F., BENEDITO, R., BREANT, C., DUARTE, A. and EICHMANN, A. (2007). The Notch ligand Delta-like 4 negatively regulates endothelial tip cell formation and vessel branching. Proc Natl Acad Sci USA 104: 3225-3230.

SUCHTING, S., HEAL, P., TAHTIS, K., STEWART, L.M. and BICKNELL, R. (2005). Soluble Robo4 receptor inhibits in vivo angiogenesis and endothelial cell migration. FASEB J. 19: 121-123

SURI, C., JONES, P.F., PATAN, S., BARTUNKOVA, S., MAISONPIERRE, P.C., DAVIS, S., SATO, T.N. and YANCOPOULOS, G.D. (1996). Requisite role of angiopoietin-1, a ligand for the TIE2 receptor, during embryonic angiogenesis. Cell87: 1171-1180.

SUTTON, A.B., CANFIELD, A.E., SCHOR, S.L., GRANT, M.A. and SCHOR, A.M. (1991). The response of endothelial cells to TGF-beta-1 is dependent upon cell shape, proliferative state and the nature of the substratum. J Cell Sci99: 777-787.
TAKAHASHI, T., YAMAGUCHI, S., CHIDA, K. and SHIBYA, M. (2001). A single autophosphorylation site on KDR/FIk-1 is essential for VEGF-A-dependent activation of PLC-gamma and DNAsynthesis in vascular endothelial cells. EMBO20:2768-2778.

TAKASHIMA, S., KITAKAZE, M., ASAKURA, H., ASANUMA, H., SANADA, S., TASHIRO, F., NIWA, H., MIYAZAKI, J., HIROTA, S., KITAMURA, Y. et al. (2002). Targeting of both mouse neuropilin-1 and neuropilin-2 genes severely impairs developmental yolk sac and embryonic angiogenesis. Proc Natl Acad Sci USA 99: 3657-3662.

TAMMELA, T. and ALITALO, K. (2010). Lymphangiogenesis: Molecular mechanisms and future promise. Cell 140: 460-476.

TAMMELA, T., ENHOLM, B., ALITALO, K. and PAAVONEN, K. (2005). The biology of vascular endothelial growth factors. Cardiovasc. Res. 65: 550-563.

TAYLOR, K.L., HENDERSON, A.M. and HUGHES, C.C. (2002). Notch activation during endothelial cell network formation in vitro targets the basic $\mathrm{HLH}$ transcription factor HESR-1 and downregulates VEGFR-2/KDR expression. Microvasc Res 64: 372-383.

TONGERS, J., RONCALLI, J.G. and LOSORDO, D.W. (2010). Role of endothelia progenitor cells during ischemia-induced vasculogenesis and collateral formation. Microvasc Res 79: 200-206.

TSE, C., XIANG, R.H., BRACHT, T. and NAYLOR, S.L. (2002). Human Semaphorin 3B (SEMA3B) located at chromosome 3p21.3 suppresses tumor formation in an adenocarcinoma cell line. Cancer Res. 62: 542-546.

UYTTENDAELE, H., HO, J., ROSSANT, J. and KITAJEWSKI, J. (2001). Vascular patterning defects associated with expression of activated Notch4 in embryonic endothelium. Proc Natl Acad Sci USA 98: 5643-5648.

VALENZUELA, D.M., GRIFFITHS, J.A., ROJAS, J., ALDRICH, T.H., JONES, P.F., ZHOU, H., MCCLAIN, J., COPELAND, N.G., GILBERT, D.J., JENKINS, N.A. et al. (1999). Angiopoietins 3 and 4: diverging gene counterparts in mice and humans. Proc Natl Acad Sci USA 96: 1904-1909.

VOKES, S.A., YATSKIEVYCH, T.A., HEIMARK, R.L., MCMAHON, J., MCMAHON, A.P., ANTIN, P.B. and KREIG, P.A. (2004). Hedgehog signaling is essential for endothelial tube formation during vasculogenesis. Development 131: 4371-4380

WANG, B., XIAO, Y., DING, B.B., ZHANG, N., YUAN, X., GUI, L., QIAN, K.X. DUAN, S., CHEN, Z., RAO, Y. et al. (2003). Induction of tumor angiogenesis by Slit-Robo signaling and inhibition of cancer growth by blocking Robo activity. Cancer Cell 4: 19-29.

WANG, H.U., CHEN, Z.F. and ANDERSON, D.J. (1998). Molecular distinction and angiogenic interaction between embryonic arteries and veins revealed by ephrinB2 and its receptor Eph-B4. Cell 93: 741-753.

WANG, S., LI, X., PARRA, M., VERDIN, E., BASSEL-DUBY, R. and OLSON, E.N. (2008). Control of endothelial cell proliferation and migration by VEGF signaling to histone deacetylase 7. Proc Natl Acad Sci USA 105: 7738-7743.

WILSON, B.D., II, M., PARK, K.W., SULI, A., SORENSEN, L.K., LARRIEU-LAHARGUE, F., URNESS, L.D., SUH, W., ASAI, J., KOCK, G.A. et al. (2006). Netrins promote developmental and therapeutic angiogenesis. Science 313: 640-644.

WOOLARD, J., WANG, W.Y., BEVAN, H.S., QIU, Y., MORBIDELLI, L., PRITCHARDJONES, R.O., CUI, T.G., SUGIONO, M., WAINE, E., PERRIN, R. et al. (2004). VEGF165b, an inhibitory vascular endothelial growth factor splice variant: mechanism of action, in vivo effect on angiogenesis and endogenous protein expression. Cancer Res. 64: 7822-7835.

XIANG, R., DAVALOS, A.R., HENSEL, C.H., ZHOU, X.J., TSE, C. and NAYLOR, S.L. (2002). Semaphorin $3 F$ gene from human $3 p 21.3$ suppresses tumor formation in nude mice. Cancer Res. 62: 2637-2643.

XUE, Y., GAO, X., LINDSELL, C.E., NORTON, C.R., CHANG, B., HICKS, C., GENDRON-MAGUIRE, M., RAND, E.B., WEINMASTER, G. and GRIDLEY, T. (1999). Embryonic lethality and vascular defects in mice lacking the Notch ligand Jagged1. Hum Mol Genet 8: 723-730.

YAMAGUCHI, A., DUMONT, D.J., CONLON, R.A., BREITMAN, M.L. and ROSSANT, J. (1993). Flk-1, an flt-related receptor tyrosine kinase is an early marker for endothelial cell precursors. Development 118: 489-498. 


\section{Further Related Reading, published previously in the Int. J. Dev. Biol.}

The seminal work of Werner Risau in the study of the development of the vascular system Domenico Ribatti

Int. J. Dev. Biol. (2010) 54: 567-572

Embryonic development of the proepicardium and coronary vessels Anna Ratajska, Elzbieta Czarnowska and Bogdan Ciszek Int. J. Dev. Biol. (2008) 52: 229-236

Vasculogenesis and angiogenesis in the mouse embryo studied using quail/mouse chimeras Michel Pudliszewski and Luc Pardanaud

Int. J. Dev. Biol. (2005) 49: 355-361

Vascular development: from precursor cells to branched arterial and venous networks Anne Eichmann, Li Yuan, Delphine Moyon, Ferdinand leNoble, Luc Pardanaud and Christiane Bréant Int. J. Dev. Biol. (2005) 49: 259-267

Parallels in invasion and angiogenesis provide pivotal points for therapeutic intervention Suzanne A. Eccles

Int. J. Dev. Biol. (2004) 48: 583-598

5 yr ISI Impact Factor $(2009)=3.253$

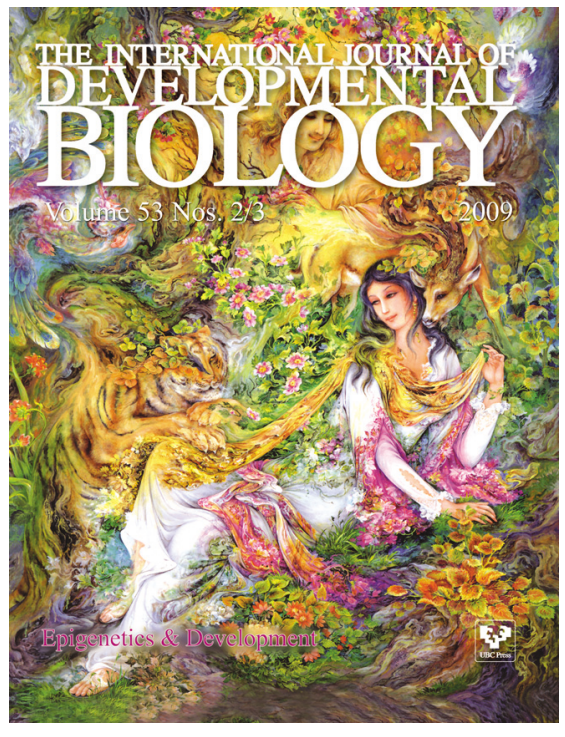

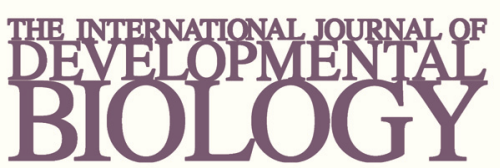

Volume 54 Nos. $6 / 7$
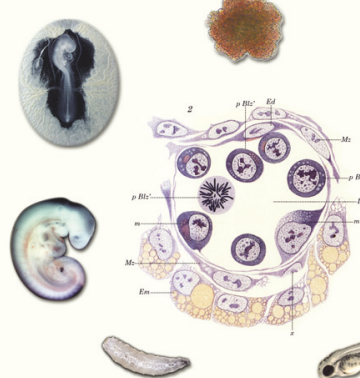

Developmental Hematopoiesis

Special Issue
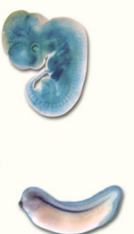

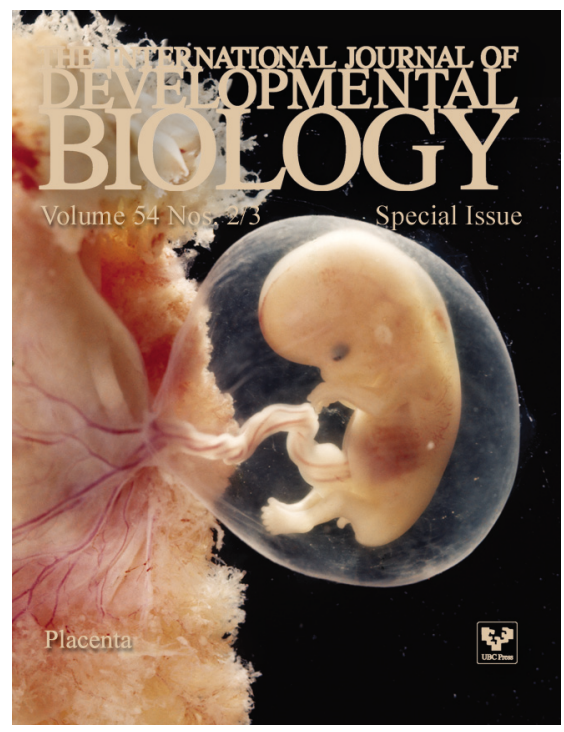

